\title{
The Existence of Customary Rights in Modern Society
}

\author{
Dr. Novyta Uktolseja,SH,MKn*, Agustina Balik, SH, MH \\ Lecturer, Faculty of Law of Pattimura University
}

\begin{abstract}
The use of the word land is not used in the formulation of Article 33 paragraph (3). This means that land (land) is one part of the earth. Land is also the most important factor not only when humans are still alive but when humans die, needing land as their final resting place. The importance of the meaning of land for human life is that human life can not be separated from the earth at all. They live on land and obtain food by utilizing land. Research is a scientific activity related to analysis and construction, which is carried out methodologically, systematically and consistently. Methodological means according to certain methods and methods; systematic is based on a system, whereas consistent means the absence of things that conflict in a particular framework. From the explanation above, it can be concluded that: 1 . The existence of customary communities' customary rights based on rules of ownership is still recognized, their traditional values are still preserved, still respected, respected, until now so that their existence is increasingly strengthened. And when times will change replaced with new regeneration. 2. Factors Affecting the Existence of Customary Rights in Modern Society can be influenced by cultural factors, structural factors, educational factors and legal factors. 3. Efforts in Maintaining the Existence of Customary Rights in Modern Communities, namely the principle of upholding traditional values.
\end{abstract}

Keywords: customary rights, society

DOI: $10.7176 / J L P G / 93-17$

Publication date: January $31^{\text {st }} 2020$

\section{Introduction}

The earth and water and the natural resources contained therein are controlled by the state and used for the greatest prosperity of the people. All existing sources of earth, water and the wealth contained therein are the right of the Indonesian people to regulate their designation. The meaning of the earth here is even broader, because the meaning of "earth" (earth) includes land and water and space. ${ }^{1}$ The use of the word land is not used in the formulation of Article 33 paragraph (3). This means that land (land) is one part of the earth. Land is also the most important factor not only when humans are still alive but when humans die, needing land as their final resting place. The importance of the meaning of land for human life is that human life can not be separated from the earth at all. They live on land and obtain food by utilizing land. ${ }^{2}$ The Indonesian people in the concept of the relationship between humans and the land place individuals and communities as an inseparable unity, that the fulfillment of one's needs for land is placed within the framework of the needs of the whole community so that the relationship is not merely individualistic, but rather collective in nature while still giving place and respect for rights individual. ${ }^{3}$

The Customary Law Community has one of the most important rights related to their living space, namely "customary rights" as stated in Article 3 of the Loga; Bearing in mind the provisions in Article 1 and Article 3, it is stated that; the exercise of customary rights and similar rights of indigenous and tribal peoples, as long as in reality they still exist, must be such that they are in accordance with national and state interests, which are based on national unity and may not conflict with other laws and regulations higher.

UUPA itself does not provide an explanation of the customary rights, except to mention, that what is meant by customary rights is beschikkingrecht in the customary law library. Customary rights as a juridical technical term are rights inherent as specific competencies in the customary law community, in the form of authority to manage and regulate land in its entirety, with internal and external applicability.

The existence of customary community's customary rights in our country may be something that is not yet widely known and understood by the customary law community itself or for modern society, other than

${ }^{1}$ Lihat dalam Pasal 1 Konvensi Chicago 1944, menyebutkan: The contracting States recognize that every State has complete and exclusive sovereignty over the air-sace above its territory. (Kesepatan bersama Negara-negara mengakui bahwa setiap negara memiliki kedaulatan yang lengkap dan eksklusif melalui udara-disimpan atau di atas wilayahnya). Dipertegas dalam Pasal 2: For the purposes of this Convention the territory of a State shall be deemed to be the land areas and territorial waters adjacent there to under the sovereignty, suzerainty, protection or mandate of such State (Untuk tujuan Konvensi ini wilayah Negara dianggap menjadi lahan dan perairan teritorial yang berdampingan dengannya di bawah kedaulatan, kekuasaan, perlindungan atau mandat dari Negara tersebut).

${ }^{2}$ Moh.Muhibbin, Penguasaan atas tanah timbul (aanslibbing) oleh masyarakat dalam perspektif hukum Agraria Nasional, Ringkasan Disertasi, Program Doktor Ilmu Hukum Fakultas Hukum Universitas Brawijaya, Malang, 2011, p. 1.

${ }^{3}$ Ibid. 
because not all regions or regions in Indonesia have customary rights, this is due to the practice of rights Ulayat is closely related to the local values of a community that have been practiced for generations. In addition, academically the study of customary rights in Indonesia is still very limited. ${ }^{1}$ Article 2 paragraph (2) of the Regulation of the Minister of Agrarian Affairs / Head of the National Land Agency Number 5 of 1999 concerning Guidelines for the Settlement of the Customary Rights Rights of the Customary Law Community, provides an explanation of the meaning "as long as in reality it still exists", according to him customary rights are recognized (their existence) if it fulfills several elements:

1. There is a group of people who still feel bound by their customary legal arrangements as citizens together with a certain legal alliance, who recognize and apply the provisions of the community in their daily lives;

2. There is a certain customary land which is the environment of the citizens of the legal community and the place to take their daily needs, and

3. There are customary law arrangements regarding the administration, control and use of customary land that is applicable and adhered to by the members of the legal community.

Land is a necessity, every human always tries to own it, it is a reality even though there are those who have never owned land. After that it will keep it going no matter what. Land can be owned by anyone, individuals, communities as a group, or legal entity. Once the land was inherited or the assets of the company even became sacred objects. Clearly, land has economic value; the more demand and demand for land, the higher the value of land, also unavoidable, which results in higher land conflicts. ${ }^{2}$

With the growing need for land, the nature of customary rights will no longer have a place in society, so that the terms and functions of customary rights will simply disappear. This also causes today's modern-day society to no longer understand what customary rights are. In addition, the need for land and the emergence of ownership rights to land which ultimately tends towards individual ownership occurs through a process. In the legal view that human relations with land are becoming increasingly important, because besides communal rights there are also individual rights. Communal rights are natural rights of humans as social beings, but for humans to survive survive must be supported by personal rights. ${ }^{3}$

The formulation of the problems to be examined in this study are:

1. How is the existence of customary rights in modern society?

2. Factors Affecting the Existence of Customary Rights in Modern Society?

3. What are the Efforts in Maintaining the Existence of Customary Rights in Modern Society?

\section{Research Methods}

Research is a scientific activity related to analysis and construction, which is carried out methodologically, systematically and consistently. Methodological means according to certain methods and methods; systematic is based on a system, ${ }^{4}$ whereas consistent means the absence of things that conflict in a particular framework.

\section{Research Results and Discussion}

\subsection{The existence of customary rights in modern society}

In general, customary land rights found in various tribes in Indonesia can be divided into two forms, namely: "ulayat rights" and "usufructuary rights". Customary rights are the right to gather or collect forest products and the right to hunt. In this communal communal right, in essence there is also an individual right to control a part of the object of ownership of the communal right. For the time being, a person has the right to cultivate and control a parcel of land by taking the results, but that does not mean that the customary rights to the land have been removed. Customary rights still cover or overcome the personal or individual rights. Customary rights will only recover if the person concerned has relinquished his control of the communal land. While usage rights allow someone to use. A plot of land for its interests is usually for paddy fields and fields that have been cleared and worked on continuously for a long time. ${ }^{5}$

Article 2 paragraph (2) of the Regulation of the Minister of Agrarian Affairs / Head of the National Land Agency Number 5 of 1999 concerning Guidelines for the Settlement of the Customary Rights Rights of the

${ }^{1}$ Daud Djubedi, Hak Ulayat laut Di Era Otonomi Daerah, Genta, cet I, Yogjakarta, 2015, p. 1.

${ }^{2}$ Djamast samosir, Hukum Adat Indonesia, Eksistensi Dalam Dinamika Perkembangan Hukum Di Indonesia, Cetakan I, CV Nuansa Aulia, Bandung, p. 98.

${ }^{3}$ Ibid. P. 100

${ }^{4}$ Soerjono Soekanto, Pengantar Penelitian Hukum, Universitas Indonesia, Jakarta, 1984, p. .42.

${ }^{5}$ Purnadi Purbacaraka Dan Ridwan Halim, Sendi-Sendi Hukum Agraria, Ghalia Indonesia, Jakarta, 1993, p. 1 
Customary Law Community, provides an explanation of the meaning "as long as in reality it still exists", according to him the existence of a customary right (existence) fulfills several elements:

a. There is a group of people who still feel bound by their customary legal arrangements as a common citizen of a certain legal alliance, who recognize and apply the provisions of the community in their daily lives;

b. There is a certain customary land which is the environment of the citizens of the legal community and the place to take their daily needs, and

c. There are customary legal arrangements regarding the administration, control and use of customary land that are applicable and adhered to by members of the legal community. ${ }^{1}$

Muhammad Bakri stated in his book "The Right to Control Land by the State (New Paradigm for Agrarian Reform)", recognition of customary rights must also be followed by recognition of the rights of indigenous peoples attached to customary rights, namely:

1. The right of indigenous peoples to control all the land in their jurisdiction (ulayat rights);

2. Rights of indigenous and tribal peoples to their customary lands, namely:

a. Right to clear land (forest)

b. The right to collect forest products

c. The right to take natural resources contained in the bowels of the earth (minerals)

d. The right to fish in rivers, lakes or beaches in their jurisdiction.

e. The right to take wild animals in the forest that others do not have. ${ }^{2}$

The existence of customary communities' customary rights is a very old right including Indonesia, which is of religious origin. This right is owned by a tribe (stam), or by a combined village (dropsbond) or usually only by a village, but never owned by an individual. ${ }^{3}$

Next is Achmad Sodiki. ${ }^{4}$ One of the concepts of land tenure that applies to traditional communities is customary rights, namely a legal community's right as an entity that has both outside and inward authority, and in it there are individual rights to land, namely rights born due to intensive and continuous exploitation. over a piece of land (empty).

From the results of research in the life of the Taniwel people in the West Seram Regency, Ambon defines customary rights / rights of land as a right which belongs to the customary law community which includes Forests, Land and Sea in accordance with historical narrative. In addition, they define customary law communities as developing traditional communities, always obeying customary law, cooperating with each other who live independently which arises spontaneously in certain areas whose establishment is not established or ordered by higher authorities or other authorities. Thus conceptually, on customary land there are rights and obligations of the customary law community in terms of protecting, preserving and preserving these customary rights in accordance with the harmony of customs left by the ancestors since generations.

In connection with the existence of customary rights of indigenous peoples, in the management of the rights of indigenous peoples in the field of land, the results of research conducted indicate that up to now the use of customary rights is carried out by indigenous peoples as members of the community who control their respective rights have rights to control other than communal land rights which are collectively / communally / togetherly allowed to allow individual land tenure / private property, in addition there are soa / relatives, and yard land

Furthermore, in the control and management of customary land rights by customary law communities, the results of research conducted through interviews with several community members showed that control, management and utilization were carried out by the State, on the other hand there were those who said control, management and use by the eyes of the landlord / Question / Klen, and by Customary Institutions

Realizing that it was impossible for the community to make arrangements, management and leadership of joint control and use, ${ }^{5}$ the task was transferred to community leaders or customary heads together with customary elders. Furthermore, according to Boedi Harsono, the delegation of duties and authority which includes the field of public law does not cover nor influence the legal relationship with the perspective of civil

\footnotetext{
${ }^{1}$ Maria S.W. Sumardjono, Tanah Dalam Prespektif Hak Ekonomi, Sosial, dan Budaya, kompas,Jakarta, 2008, p. 50.

${ }^{2}$ Muhamma Bakri, Hak Menguasai Tanah Oleh Negara (Paradigma Baru Untuk Reforma Agraria), Universitas Brawijaya Press (UB PRESS), Malang, p. 99.

${ }^{3}$ van Vollenhoven, Ichtisar Lengkap De Indonesier en zijn grond jilid 1 (Terjemahan Soewargono), Yayasan Badan Penerbit Gajah Mada, Jogjakarta, 1956,P.P. 16-17

${ }^{4}$ Achmad Sodiki, Penataan Kepemilikan Hak Atas Tanah Di Daerah Perkebunan Kabupaten Malang (Studi Tentang Dinamika Hukum), Disertasi Program Pasca Sarjana Universitas Airlangga, Surabay, 1994, p. 8.

${ }^{5}$ Husen Alting, Dinamika Hukum dalam Pengakuan Dan Perlindungan Hak Masyarakat Hukum Adat Atas Tanah (Masa Lalu, Kini Dan Masa Mendatang), LaksBang PRESSindo, Yogyakarta, 2010, p. 56-57
} 
law. The right of ownership of the shared land remains with the relevant customary law community in the sense that it belongs to the shared community and does not transfer to the Customary Head. ${ }^{1}$

Based on the above definition, according to Husen Alting, the customary rights to land are the collective (collective) rights to the land parcels that are used by the community continuously as a place to make a living. So that its utilization does not cause conflict in the future, the management is left to a group of people (traditional elders) to regulate the designation, use and use of it, as well as to preserve the continuation of customary rights over land. based on permission from the traditional authorities. ${ }^{2}$

Based on the understanding or a brief description of the experts mentioned above it can be said:

1. That the customary law community still continues to carry out its customary rules in accordance with the traditions that have been established in the community and are led by traditional elders.

2. Whereas customary rights are strong and fulfilled rights which for generations are still held by her to be controlled collectively or collectively in fulfilling the life between members of customary law communities together and the needs of each member of customary law communities.

3. Whereas in regulating the designation, use, maintenance and utilization of customary land rights there is no interference from outside parties and is intended only for customary law communities.

The use of customary land rights by customary law communities is used for farming, building community housing, public infrastructure, and being used as cattle land. Furthermore, those who can use customary land rights are domestic children, outsiders / individuals (in this case must enter into an agreement relating to the use of land), private parties (companies), and the government of the country, besides Husen Alting. said that for people who control land with permanent ownership rights are recognized in the principle of customary rights, but very much depends on the fact whether the land is controlled and used continuously or only temporarily.

Appoint certain special offices in charge of the relevant federal jurisdiction. The officers were often referred to as jarring (Minangkabau), jungle (Minahasa), head of chin (Ambon), slime (Bali). In addition to these special officers, there are usually border patrols.

c. He made abusive letters or charters issued by the former kings, issued by the decisions of the royal judges or judges of the former colonial Dutch government or by other officials of the royal court. ${ }^{3}$

Between this right of association (ulayat rights) and the rights of each of its citizens (individual rights) there is a mutual reciprocal relationship. This means that the more intensive the relationship between the individual, the community member, and the land concerned, the more or less the force of the communal customary right to the said land; but on the other hand, if the individual's relationship with the land becomes more and more blurred, because for example the land is then not maintained or less maintained, then the said land will gradually return to the authority of communal land rights. So the relationship or interrelation between customary rights and individual rights to each other is in a state of bloating and deflating, depending on the intensity (cultivation) of land work by individuals. ${ }^{4}$ carried out by:

The alliance of indigenous and tribal peoples in maintaining and maintaining customary rights is

a. The alliance tried to put boundaries around its territory. But this effort usually cannot be carried out perfectly, especially if the community of the fellowship, the place of residence is scattered in small dukes or if the area of the fellowship, covers large vacant lands.

b. Appoint certain officials specifically tasked with supervising the territorial powers of the said fellowship. These officers are often called jarring (Minangkabau), teterusan (Minahasa), chief of kewang (Ambon), and the temple hill (Bali). Besides this special officer, border patrols are usually held.

c. Carrying out letters of pikukuh or charter issued by the former kings, which were issued as decisions of royal judges or judges of the former Dutch colonial government or by other authorized civil service officials.

The same is true in the interview conducted by the taniwel people that the understanding or determination of the customary law community in the local state or village is limited to the determination of tenure rights according to the historical speech of the Dutch Pal in 1617, Monument, Alor / Javanese , Mountain, Water, Stone, Bamboo, Wood, how to set such limits in accordance with the agreement agreed upon by customary elders so that the customary law community lives in harmony without any conflict of land.

${ }^{1}$ Boedi Harsono, Opcit, p. 182-183

${ }^{2}$ Husen Alting, Opcit, p. 57

${ }^{3}$ Ibid, p. 59

${ }^{4}$ Bushar Muhammad, Pokok-Pokok Hukum Adat, PT Pradnya Paramita, Jakarta, 1981, p. 103. 


\subsection{Factors Influencing the Existence of Life Rights in Modern Society.}

As the existence of tenure rights in society has become increasingly marginalized due to the age-old development of society, it is more important for individuals to give up their traditional lives and thus impact the land they are entitled to by means of protecting their land by registering land to ensure legal certainty. So the shifts in collective / collective land ownership have diminished. ${ }^{1}$

The same thing was obtained in the results of interviews conducted with the Taniwel community that the understanding or determination of customary law community boundaries in the local country or village was limited to the determination of customary land boundaries in accordance with historical utterances in the form of the Dutch Pal in 1617, Tugu, Alor / Gorge, Mountain, Water, Stone, Bamboo, Wood, how to set the boundary in accordance with the agreement that was jointly agreed upon by the traditional elders so that the customary law community lived harmoniously without any conflicts over land issues.

\subsection{Efforts in Maintaining the Existence of Customary Rights in Modern Society.}

In the philosophy of life the customary law community is not the same as the running of a machine. Everyone has their own feelings and abilities. An individual therefore needs another treatment and another individual. Individual will and its ideals need to be considered in managing social life. And that in the sense of "orderly society" or "orderly people", it is all required to get the attention they deserve. That way life, both for individuals and for living together, becomes varied in its full form of style. And that determines social life requires an attitude and steps are not like running a machine. ${ }^{2}$

Furthermore, the existence of customary rights in a global society that is now plaguing indigenous peoples is in a position as a party to survive with continuous advancements, which always look advanced and increasingly sophisticated and show quick and precise results thanks to the work of global forces. It is very tempting to these advances and indigenous and tribal peoples can accept it and try to follow it with an attitude of acceptance and willingness to follow progress and the results of these forces in the sense that indigenous peoples give concessions to the principles and philosophies of life with global power. ${ }^{3}$

In awarding the concession, each customary principle is as follows: ${ }^{4}$

a. Togetherness must give concessions to individualism. This is because modern life is individualistic.

b. The principle of customary universalism must give concessions to the principle of secularism. Because modern is secular

c. The principle of customary idealism must give concessions to the principle of materialism. This is because modern is materialistic

d. the customary principle of virtuous humanity, knowing shame and tolerance, must give concessions to the principle of people who dare to compete in pursuit of material benefits and prosperity for themselves without shame

Based on the descriptions above, then normatively, the legal basis for the development of customary law communities along with their origins and the existence of their customary rights in legislation can be described as follows:

\section{The 1945 Constitution of the Republic of Indonesia}

Provisions in the 1945 Constitution of the Republic of Indonesia relating to the concept of the relationship between land (in the agrarian concept) and humans themselves (in the concept of indigenous and tribal peoples if further examined. Article 18B paragraph (2) states that "the State recognizes and respects the unity customary law community unit and its traditional rights as long as they are still alive and in accordance with the development of the community and the principles of the Unitary State of the Republic of Indonesia, which is regulated in the law., where there are conditions which constitutionally must be met, namely:

1) As long as it's alive

2) In accordance with community development

3) The principle of the unitary state

4) Regulated by law

The requirements for indigenous peoples and their customary rights carried out by the 1945 Constitution of the Republic of Indonesia have a history that can be traced back to the colonial period $\mathrm{AB}$ (1848), RR (1854) and IS (1920 and 1929) said that native and eastern foreigners who did not want to submit to

${ }^{1}$ Sarkawi, Hukum Pembebasan Tanah Hak Milik Adat Untuk Pembangunan Kepentingan Umum, Graha Ilmu, Yogyakarta, 2014, p. . 29. 317-318

${ }^{2}$ Moh. Koesnoe, Kapita Selekta Hukum Adat Suatu Pemikiran Baru, Varia Peradilan, IKAHI, Jakarta, 2002, p.

${ }^{3}$ Ibid, p. 319

${ }^{4}$ Ibid, p. $319-320$ 
European Civil law, enacted religious laws, institutions and customs of society, as long as it does not conflict with generally recognized principles of justice. ${ }^{1}$

Such requirements are discriminatory because they are closely related to the existence of culture. The orientation of the emerging requirements is an attempt to subdue customary / local law and try to turn it into formal / positive / national law. On the other hand it also has a presumption that indigenous peoples are communities that will be "eliminated" to become modern societies, who practice modern economic production, distribution and consumption patterns.

The 1945 Constitution of the Republic of Indonesia also regulates the state's control over natural resources, including the relationship between the state and land, as referred to in Article 33 paragraph (3), which states that "the earth and water and the natural resources contained therein are controlled by the state and used for the greatest prosperity of the people"

The principles or constitutional values in controlling natural resources in economic activities of natural resources do not state the importance of accommodating community collective rights such as communal rights. Although actually collectivism in natural resource economics can be drawn from Article 33 paragraph (1) of the 1945 Constitution of the Republic of Indonesia (the economy is prepared as a joint effort based on the principle of kinship), but paragraph (4) of Article 33 of the 1945 Constitution of the Republic of Indonesia NRI is not a complement to Article 33 paragraph (1) cumulatively, but rather as a series of additional values that are alternative. This gives the consequence that the constitutionality of state control over natural resources is not single.

Furthermore, in addition to article 18B paragraph (2) of the 1945 Constitution of the Republic of Indonesia which regulates the recognition of indigenous and tribal peoples, there are several articles relating to indigenous and tribal peoples, including the following:

Article 28A of the 1945 Constitution of the Republic of Indonesia

"Every person has the right to live and has the right to defend his life and lives."

Article 28B of the 1945 Constitution of the Republic of Indonesia

1. Everyone has the right to form a family and carry on descendants through a legal marriage

2. Every child has the right to survival, growth and development and is entitled to protection from violence and discrimination

Article 28D of the 1945 Constitution of the Republic of Indonesia

1. Everyone has the right to recognition, guarantee protection and fair legal certainty and equal treatment before the law.

2. Everyone has the right to work and to receive fair and appropriate compensation and treatment in an employment relationship.

3. Every citizen has the right to have the same opportunity in government.

4. Everyone has the right to citizenship status

Article 28I of the 1945 Constitution of the Republic of Indonesia

1. The right to life, the right not to be tortured, the right to freedom of thought and conscience, the right to religion, the right not to be enslaved, the right to be recognized as a person before the law, and the right not to be prosecuted on the basis of a retroactive law are human rights that are retroactive cannot be reduced under any circumstances.

2. Everyone has the right to be free from discriminatory treatment on any basis and has the right to get protection against such discriminatory treatment.

3. Cultural identity and traditional community rights are respected in line with the times and civilizations.

4. Protection, promotion, enforcement and fulfillment of human rights are the responsibility of the state, especially the government.

5. To uphold and protect human rights in accordance with the principles of a democratic rule of law, the implementation of human rights is guaranteed, regulated, and stated in legislation

Article 28J of the 1945 Constitution of the Republic of Indonesia

1. Everyone must respect the human rights of others in the orderly life of the community, nation and state.

2. In exercising their rights and freedoms, every person is obliged to submit to the limitations established by law with the sole purpose of guaranteeing the recognition and respect for the rights of freedom of others and to fulfill fair demands in accordance with moral considerations, religious values , security and public order in a democratic society.

${ }^{1}$ Rikardo Simarmata, Pengakuan Hukum terhadap Masyarakat Adat di Indonesia, UNDP, Jakarta, 2006, p. 309- 
The philosophy of the BAL in accordance with Article 33 paragraph (3) of the 1945 Constitution of the Republic of Indonesia displays two key words namely that the state as an organization of power obtains authority from the Indonesian people to control the earth (including land), water, and natural resources contained therein, and that the controlling right of the state is used with the aim of achieving the greatest prosperity of the people. In other words, the constitutional formulation is related to the concept of social welfare, as intended in the provisions of Article 33 paragraph (3) of the 1945 Constitution of the Republic of Indonesia including:

a) The main material about the management of the earth, water and natural resources contained therein;

b) The concept of the right to control the state;

c) Management objectives

The state's authority to control does not only contain the authority to regulate, as stated in Article 2 paragraph (2) of the BAL, but also includes the authority to make policies, conduct management, management and supervision of the contents of its authority consisting of three things, namely with respect to (1) regulated objects (earth, water and natural resources contained therein); (2) legal relations between subjects and objects; and (3) legal relations and legal actions related to the regulated object. The expansion of the meaning of the State's Right to Control is in accordance with the decisions of the Constitutional Court (hereinafter referred to as the Constitutional Court) in the judicial review of laws relating to natural resources. Likewise with respect to the meaning of the people's prosperity, the Constitutional Court has provided the benchmarks namely; (1) the benefits for the people; (2) equitable utilization; (3) people's participation in determining their benefits; and (4) respect for people's rights.

\section{Law Number 5 of 1960 concerning Basic Agrarian Regulations (UUPA)}

The relationship between the provisions of Article 33 paragraph (3) of the 1945 Constitution of the Republic of Indonesia and the LoGA constitutes a legal source (material) for regulating the relationship between the state and land as referred to in the provisions of Article 2 of the LoGA. This is also implicitly emphasized in the dictum considering the LoGA. Furthermore, in the General Explanation of UUPA number I, it was formulated that the national agrarian law must realize the incarnation of the State's spiritual principles and national ideals namely Pancasila and specifically the implementation of the

Provisions of Article 33 of the 1945 Constitution of the Republic of Indonesia.

Besides the explanation of the 1945 Constitution of the Republic of Indonesia, as mentioned above, there are several articles relating to indigenous and tribal peoples as stipulated in the LoGA which are contained in the following articles:

Article 3 of the BAL

"Keeping in mind the provisions in articles 1 and 2 of the implementation of customary rights and similar rights from indigenous peoples, as long as in reality. still exists, must be such that it is in accordance with national and state interests, which are based on national unity and may not conflict with other higher laws and regulations.

Article 5 of the BAL

Agrarian law that applies to earth, water and space is customary law, as long as it does not conflict with national and state interests, which are based on national unity, with Indonesian socialism and with the regulations contained in this Act and with other laws and regulations, everything by heeding the elements that rely on religious law.

Article 22 paragraph 1 of the BAL

Occurrence of ownership rights under customary law is regulated by government regulations. Paragraph (4) that the controlling right of the said State can be empowered to the autonomous regions and customary law communities only as necessary and not in conflict with national interests, according to the provisions of government regulations.

Article 26 paragraph 1 of the BAL

Buying and selling, exchanging, giving, giving with will, giving with customary law and other legal actions intended to transfer ownership and control are regulated by government regulations.

Article 56 of the BAL

As long as the law regarding ownership rights as mentioned in article 50 paragraph (1) has not yet been formed, the provisions of the local customary law and other regulations concerning land rights that give authority as or similar to those referred to in Article 20 as long as it does not conflict with the soul and the provisions of the law. 
3. Law No. 5 of 1967 concerning Forestry Principles jo Law No. 41 of 1999 concerning Forestry (hereinafter referred to as Law No. 41/1999).

Article 1 paragraph 6

Customary forest is state forest which is within the territory of customary law community so that although customary forest is classified as state forest area, in fact, the state recognizes the existence of customary law community territory.

Article 4 paragraph 3

The control of forests by the State continues to pay attention to the rights of indigenous and tribal peoples, as long as in reality they still exist and are recognized, and do not conflict with national interests.

Article 5 paragraph (2), paragraph (3)

(2) State forest as referred to in paragraph (1) letter a, can be in the form of customary forest. (3) The government determines the status of the forest as referred to in paragraph (1) and paragraph (2); and customary forests are determined as long as in reality the relevant customary law communities still exist and are recognized. Paragraph (2) if in the development of the relevant customary law community no longer exists, the customary forest management rights will return to the Government.

Article 17 paragraph 2

Establishment of forest management areas requires management units to take into account land characteristics, forest types, forest functions, watershed conditions, socio-cultural, economic, institutional aspects of local communities including customary law communities and Government administrative boundaries.

Article 37 paragraph (1)

Customary forest utilization is carried out by the relevant customary law community, in accordance with its function.

Article 52 paragraph 2

In carrying out research and development, education and training and forestry counseling, it is obligatory to pay attention to science and technology, traditional wisdom and the socio-cultural conditions of the community.

Article 67 paragraph 1

Indigenous and tribal peoples insofar as in reality they still exist and are recognized as having the right to:

(a) collect forest products to fulfill the daily needs of the indigenous peoples concerned;

(b) carrying out forest management activities based on applicable customary law and not in conflict with the law; and

(c) get empowerment in order to improve their welfare.

Article 67 paragraph (2)

Inauguration of the existence and elimination of the customary law community as referred to in paragraph (1) shall be stipulated by a Regional Regulation.

\section{Law Number 39 of 1999 concerning Human Rights}

The existence of indigenous and tribal peoples in relation to the protection of the rights of indigenous and tribal peoples is also stated in Article 6 paragraph (1) and (2) of Law Number 39 of 1999 concerning Human Rights as follows:

(1) In the context of upholding human rights, differences and needs within the customary law community must be considered and protected by law, the community and the Government.

(2) Cultural identity of indigenous and tribal peoples, including rights to customary land is protected, in line with the times.

Recognition of the rights of indigenous peoples is not only in their existence but also the principles of rights and obligations, ownership principles, tenure principles, principles of use, and also the principles of management of indigenous peoples' lands.

5. Law Number: 6 of 2014 concerning Villages and Government Regulation Number: 43 of 2014 concerning Regulations for the Implementation of Law Number: 6 of 2014.

The newly issued village law is adjusted to the development of the era which must undergo a process of uniformity carried out by the government, but it needs to be seen that each region has different characteristics and can eliminate the customs and functions of the function of the customary law community. there are outside of Java and Madura. this matter concerns the position of the customary law community as regulated in Article 97 states that;

(1) Determination of Customary Villages as referred to in Article 96

qualify: 
a. the traditional law community unit and its traditional rights are actually still alive, both territorial, genealogical and functional in nature;

b. ustomary law community unit and their traditional rights are seen in accordance with community development; and

c. customary law community unit and their traditional rights in accordance with the principles of the Unitary State of the Republic of Indonesia.

(2) Unity of customary law communities and their traditional living rights as referred to in paragraph (1) letter a must have territories and at least meet one or a combination of the following elements:

a. people whose citizens have shared feelings in groups;

b. customary government institutions;

c. property and / or custom objects; and / or

d. the device of customary law $n$

(3) The unity of the customary law community and their traditional rights as referred to in paragraph (1) letter $b$ is deemed appropriate to the development of the community if:

a. its existence has been recognized under the applicable law as a reflection of the development of values that are considered ideal in today's society, both laws that are general or sectoral in nature; and

b. the substance of such traditional rights is recognized and respected by members of the community concerned and the wider community and does not conflict with human rights.

(4) A customary law community unit along with its traditional rights as referred to in paragraph (1) letter $\mathrm{c}$ is in accordance with the principles of the Unitary State of the Republic of Indonesia if the customary law community unit does not interfere with the existence of the Unitary State of the Republic of Indonesia as a political unit and legal entity which:

a. does not threaten the sovereignty and integrity of the Unitary Republic of Indonesia; and

b. the substance of the customary law norms is appropriate and does not conflict with the provisions of the legislation.

\section{Government Regulations}

A. PP Number: 24 of 1997 concerning Land Registration.

Article 8 (3). Membership of the Adjudication Committee can be added by a member who is indispensable in assessing the legal certainty of data regarding parcels of land in the village / kelurahan area concerned.

In this article it does not rule out the possibility that one of the members of the committee is a village or country leader or king who knows about ownership of customary lands. Registration of former customary rights requires confirmation of the type of old right and affirmation of the conversion of these rights into new rights after which registration can be done. For the implementation of the registration must be in accordance with the provisions of PP No. 24 of 1997, namely:

1. Customary property rights before conversion according to customary law of land rights obtained by way of:

a. clearing forest land or scrub land

b. inherit the land

c. receive land due to purchase

2. Customary Rights after Conversion.

With the enactment of the LoGA, the occurrence of ownership rights to the land above is regulated in Article 2 of the LoGA which states:

a. Occurrence of ownership rights under customary law is regulated by Government Regulation

b. In addition to the manner referred to in paragraph (1) of this article, ownership rights occur due to: Determination of the Government according to the manner and conditions stipulated by Government Regulations and provisions of the Law.

Conversion of ownership rights to land is the right to land obtained from clearing land and clearing forests by working on it continuously. Property rights to this land must be converted based on the rights that exist in the LoGA, Therefore the attitude and philosophy of the conversion has 5 (five) fundamental principles, namely:

1. National Principles

2. Principles Recognition of previous land right

3. Legal Importance

4. Adjustments to Conversion Provisions

5. Status quo of previous rights ${ }^{1}$

\footnotetext{
${ }^{1}$ Iman Sudiyat, Hukum Adat Seketsa Asas, Liberty, Bandung, 1987, p. 9
} 
The procedure for affirming conversion and registration has been regulated in the Minister of Agriculture and Agriculture No. 2 of 1962 distinguished between With the explanation above, the purpose of the conversion of land rights to land rights under the LoGA system is in addition to creating a unification of land law in the country by recognizing the previous land rights to be adjusted according to the provisions contained in the LoGA and to guarantee legal certainty, also aims that land rights can function to accelerate the realization of a just and prosperous society as envisioned by the 1945 Constitution of the Republic of Indonesia Article 33 paragraph (3).

Article 9: Objects for land registration include:

a. Plots of land that are owned with ownership rights, usufructuary rights, usufructuary rights and usufructuary rights;

b. Land management rights;

c. Waqf land;

d. Ownership rights for flats;

e. Mortgage right

f. State Land.

Article 24 paragraph (2)

In the event that no or no more complete means of evidence as referred to in paragraph (1) are available, bookkeeping rights can be carried out based on the physical mastery of the relevant parcels of land for 20 (twenty) years or more in a row by the applicant for registration and its predecessors, provided that:

a. the control is carried out in good faith and openly by the person concerned as entitled to the land, and is strengthened by the testimony of a person who can be trusted;

b. Such control either before or during the announcement as referred to in Article 26 shall not be disputed by the adat law community or the village / kelurahan concerned or other parties.

he provisions of paragraph (2) provide a way out if the right holder cannot provide proof of ownership as referred to in paragraph (1), whether in the form of written evidence or other credible forms. In such case bookkeeping rights can be done not based on proof of ownership but based on evidence of physical control that has been carried out by the applicant and his predecessor.

Bookkeeping rights according to this paragraph must fulfill the following conditions:

a. that the control and use of the land concerned is carried out in a real and good manner for 20 (twenty) years or more in a row;

b. that the reality of the control and use of the land has not been contested so far and is therefore considered to be recognized and justified by the adat law community or the village / kelurahan concerned

c. that these are reinforced by the testimonies of people who can be trusted;

d. that an opportunity has been given to another party to submit an objection through an announcement as referred to in Article 26;

e. that research has also been carried out regarding the truth of the things mentioned above;

f. that finally the conclusion regarding the status of the land and its rights holders is outlined in a decision in the form of recognition of the relevant rights by the Adjudication Committee in systematic land registration and by the Head.

Land Office in sporadic land registration.

\section{PP Number: 76 of 2001 concerning General Guidelines for Regulations Regarding Villages}

Article 39 paragraphs 1 and 2

(1) The Regional Government must recognize and respect the customs and traditional institutions in its territory as referred to in Law Number 39 of 1999 concerning Human Rights.

(2) Regional Governments can stipulate various policies in the effort to empower, preserve and develop customs and traditional institutions in their regions.

Article 40 paragraphs 1 and 2

(1) Further arrangements regarding the empowerment of the preservation and development of customs and traditional institutions are stipulated in district regulations.

(2) Regency Regional Regulations referred to in paragraph (1), contain material including;

a. Empowerment, preservation and development mechanism

b. Position, duties and functions of traditional institutions

c. The rights, authorities and obligations of adat institutions include the authority to settle traditional disputes

d. Organizational Structure and

${ }^{1}$ A.P.Parlindungan, Konversi Hak-hak atas tanah , Mandar Maju, Bandung, 1990, p. 6 
e. Relationships with government organizations, both village and district governments.

\section{PP Number: 6 Regarding Forest Exploitation and Collection of Production Forest Products}

Article 1 (18): Whereas the local community are groups of NRI people who live in one or around the forest and have characteristics as a community, based on kinship, common livelihoods related to the forest (profession), history, attachment shared accommodation and other community bonding factors.

Article 27 paragraph (1): Whereas the customary law community, as long as in reality there is still a dam, is recognized based on this government regulation, it is given the right to collect forest products to fulfill daily living needs.

\section{Presidential Regulation Presidential Decree Number 34 of 2003 concerning National Policy in the Field} of Land.

Article 2 paragraph (2) that part of the authority of the government in the field of land is carried out by the district / city government in the form of determining and resolving the ulayat land issue.

\section{Ministerial Decree / Regulation}

a. Decree of the Minister of Forestry Number. 251 / Kpts-II / 1993 concerning Provisions on the Rights of Collection of Forest Products by the Customary Law Community;

Article 1). The decree states that in this decree what is meant by the rights of indigenous and tribal peoples is the right of a certain group of legal communities that still exist to collect forest products both timber and non-timber from the area of forest concessions.

b. Minister of Home Affairs Regulation No. 3 of 1997 concerning Empowerment and Preservation and Development of Customs;

Article (8) Customary institutions are domiciled as a forum for consultative organizations or agreement of customary heads or adat holders, customary elders and other traditional leaders or leaders who are outside the composition of government organizations in the provinces, districts and villages.

Article 9. Customary institutions have the following rights and authorities:

a. Representing the indigenous people out, namely in matters relating to and influencing adat

b. Manage customary rights and or customary assets to improve community progress and living standards for the better

c. Settling disputes concerning community matters.

d. Minister of Home Affairs Regulation Number. 9 of 1998 concerning Community Participation in Regional Spatial Planning.

The participation of indigenous peoples is explicitly stated in the process of planning, implementing, monitoring, submitting objections and obtaining compensation for changes caused by spatial planning. d. Mentari Agrarian Regulation / Kapala National Land Agency Number. 5 of 1999 concerning Guidelines for the Settlement of Customary Community Rights.

Article 1 paragraph (1) and (2)

(1). Customary and similar rights from customary law communities (hereinafter referred to as ulayat rights), are authorities which according to customary law belong to certain customary law communities over certain areas which are the environment of their citizens to take advantage of natural resources, including land, in these areas, for their survival and life, arising from outward and inward relations down and down between the customary community and the area concerned.

(2). Customary land is a piece of land on which there are customary rights of a particular customary community. Article 4 paragraphs (1) and (2)

(1). The control of parcels of land including communal land as referred to in Article 2 by individuals and legal entities can be carried out:

a. by members of the customary law community concerned with tenure rights according to the provisions of the applicable customary law, which if desired by the holder of his right can be registered as the right to land according to the provisions of the Basic Agrarian Law.

b. By government agencies, legal entities or individuals who are not members of the customary law community concerned with land rights according to the provisions of the Basic Agrarian Law based on the granting of rights from the State after the land is released by the customary law community or by its citizens in accordance with legal provisions and procedures applicable customs.

(2). The release of customary land as referred to in paragraph 1 letter $b$ for agricultural purposes and other needs requiring the right to use land or the right to use can be carried out by the customary law community by giving up the use of the land for a certain period of time, so that after that period expires, or after the land these are no longer used or abandoned so that the right to use the business or the right to use is abolished, then the next use must be done based on the new agreement of the indigenous peoples concerned as long as the customary rights of the customary community are still in accordance with the provisions of Article 2. 
11. Regulation of the Minister of Rural Development and Transmigration Areas Number: 1 of 2015 concerning Guidelines for Authority Based on Village-Based Origins and Local Authority

Article 1. Referred to in this Ministerial Regulation as:

(1). Village is a village and a customary village or what is referred to by another name, hereinafter referred to as Village, is a legal community unit that has the authority to manage and manage government affairs, the interests of the local community based on community initiatives, original rights, and / or traditional rights recognized and respected in the government system of the Unitary Republic of Indonesia.

(2) Village Authority is the authority owned by the Village including authority in the area of administering Village Government, implementation of Village Development, Village Community Development, and Empowerment of Village Communities based on community initiatives, origin rights and village customs.

(3). Authority based on original rights is a right that is a living legacy and the initiative of the Village or the initiative of the Village community in accordance with the development of community life.

(4). The village-scale local authority is the authority to regulate and manage the interests of the village community that has been run by the village or is able and effectively carried out by the village or that arises because of the development of the village and the village community's practices.

(5). Village Government is the administration of government affairs and the interests of the local community in the government system of the Unitary Republic of Indonesia.

(6). Village Government is the head of the Village or referred to by another name assisted by the Village apparatus as an element of Village Administration.

(7). The Village Consultative Body, or what is referred to by other names, is an institution that carries out governmental functions whose members are representatives of the village population based on regional representation and democratically determined.

(8). Village Deliberation or referred to by other names are deliberations between the Village Consultative Body, the Village Government, and elements of the community organized by the Village Consultative Body to agree on strategic matters.

(9). Village Regulations are laws and regulations determined by the Village Head after being discussed and agreed with the Village Consultative Body.

(10). Village Development is an effort to improve the quality of life and life for the maximum welfare of the village community.

Article 3 . The authority based on the origin rights of the customary village includes:

a. structuring the organizational and institutional systems of indigenous peoples;

b. customary law institutions;

c. ownership of traditional rights

d. traditional village cash land management;

e. customary land management;

f. agreement in the life of the indigenous village community;

g. filling in the position of the head of the customary village and the customary village apparatus; and

h. the term of office of the head of the customary village.

Article 4: The government, provincial government and regency / city government must recognize, respect and protect authority based on the right of origin as referred to in article 2

Formally Minister of Rural Development and Transmigration Ministerial Regulation Number: 1 of 2015 concerning Guidelines for Authority Based on Origins and Village-Scale Local Authority recognizes the diversity of indigenous and diverse indigenous people

12. Regional Regulation Number 14 of 2005 Concerning Re-Establishment of the Country as a Unit of Customary Law Communities within the Government of Maluku Province

In his consideration stated:

1. The status and existence of indigenous and tribal peoples is recognized constitutionally by the 1945 Constitution along with various other implementing regulations.

2. Recognition of the status, position and existence of customary law communities as referred to in letter (a) including customary law communities in Maluku as a country or referred to by other names, which have been known since ancient times and in fact continue to grow and evolved over time to the present. 
This regulation provides a space that customary law and any traditional characteristics related to customary law communities are recognized and respected and even used in the case of the use of the term reused as a characteristic of the mention of dwellings in a certain area that has existed from time immemorial.

\section{International Convention}

Recognition and development of the existence of indigenous and tribal peoples in addition to those contained in national statutory regulations, can be seen in international conventions. Attention to the importance of respecting and protecting customary rights has been realized with the commitment of the international community namely the Indigenous People Year by the United Nations (UN) in 1993, including:

1. RIO Declaration 1992 and 1992 Agenda 21 Article 22 the need for recognition and empowerment of indigenous and tribal peoples, where indigenous and tribal peoples are expected to receive more equitable treatment.

2. International Labor Organization (ILO) Convention 169 of 1989:

Article 6 contains the principles of participation and consultation in the entire decision-making process that causes impacts on these community groups at the national level.

3. International Declaration of the International Alliance of Indigenous-Tribal Peoples of the Tropical Forest (1996) that;

Indigenous peoples recognize that for the long-term interests of their lives they will use forest resources sustainably and respect the interests of environmental conservation. Indigenous peoples recognize that the ability of conservation organizations can help improve self-help development and obtain mutually beneficial relationships based on mutual trust, openness and accountability.

4. The United Nations Declaration and Program for Action to Combat Racism and Racial Discrimination (UN Declaration \& Program of Action to oppose racism and racial discrimination) held in Geneva in 1978 in Article 21 recognizes the right of indigenous peoples to preserve their traditional economic and cultural structures, including language, and special relations with land and natural resources should not be taken away from them.

5. The World Council of Indigenous Peoples (WCIP) in Kiruna in Sweden in 1966 emphasized that the rights of indigenous peoples to land were full ownership rights, regardless of whether they held official rights issued by the authorities or not.

Recognition and protection of the rights of indigenous peoples is indeed important, because it must be recognized traditionally that indigenous peoples are born and existed long before the Unitary State of the Republic of Indonesia was formed. However, in the development of these traditional rights, it must adjust to the principles and spirit of the Unitary State of the Republic of Indonesia through normative requirements in the legislation itself. On many sides, these normative requirements become obstacles to the existence of the rights of indigenous peoples. ${ }^{1}$ because:

a. In the practice of conducting development, the phrase "as long as it is still alive and in accordance with the development of society and the principles of the Unitary State of the Republic of Indonesia" means that the presence of the rights of indigenous and tribal peoples as a recognized institution as long as it does not conflict with the spirit of development, so there is an impression that the government neglects community rights customary law. While factually in the community there is a spirit of strengthening the rights of indigenous and tribal peoples.

b. In the 1945 Constitution it is stated that the traditional rights of indigenous and tribal peoples are respected as long as they are still alive and in accordance with the development of society and the principles of the Unitary State of the Republic of Indonesia, which are regulated in the law.

In providing an interpretation of Article $18 \mathrm{~B}$ paragraph (2) of the 1945 Constitution, according to Jimly Asshiddiqie, it is stated that it is necessary to note that this recognition is given by the state (i) to the existence of a customary law community and its traditional rights; (ii) Recognized existence is the existence of customary law community units; (iii) the indigenous and tribal peoples are indeed alive (still alive); (iv) In certain environments (lebensraum); (v) Recognition and respect is given without ignoring the feasibility measures for humanity in accordance with the level of development of the nation's existence; (vi) that recognition and respect must not reduce the meaning of Indonesia as a state in the form of a unitary state of the Republic of Indonesia. This provision gives recognition and respect to the customary law community (adatrechtgemeenschappen) which is a basic concept or pillar of customary law. ${ }^{2}$

${ }^{1}$ Naskah Akademis RUU Pengakuan dan Perlindungan Hak Masyarakat Hukum Adat, p. 2.

${ }^{2}$ H. Abdurrahman, Peranan Hukum Adat Dalam Aplikasi Kehidupan Berbangsa Dan Bernegara Dalam Majalah Hukum Nasional, No. 1 Tahun 2007, Hal.191 BPHN Departemen Hukum Dan HAM RI 
The existence of indigenous and tribal peoples in Indonesia is an inevitable matter. The existence of indigenous peoples today also needs to get optimal attention, given that the existence of indigenous peoples and their customary laws has experienced a degradation in recognition. A number of legislative initiatives that have been and are in process now are a form of "re-contracting" between the state and indigenous and tribal peoples who are in a different social, political context from the past. Therefore, all programs aimed at the customary law community must also be with a different new spirit. ${ }^{1}$

This paradigm shift no longer positions the customary law community as a traditional group that needs to be modernized by measuring the people of the city, who 'urgently' changes the socioeconomic pattern of the indigenous people into the welfare category according to the authorities. This is in line with the spirit of the era that goes beyond the notion of linearity from traditional to modern. In this old understanding, all indigenous peoples must be modernized, changed their lifestyle and way of production into a single model that is easily controlled. ${ }^{2}$

The perspective that all societies can be engineered to change from traditional to modern has begun to be abandoned. Replaced with the view that society will determine its own changes as a subject that has its own history, civilization and interests.

From the explanation above, it can be said that: ${ }^{3}$

Most of our customary law communities consist of a variety of traits and patterns of customary law, each of which regions or countries teach their customary rules which were taught from a small age and raised in a customary religious legal environment that is so religiously religious that there are still many customary law communities that still carry out their customary values and there are some indigenous people who have begun to accept and follow increasingly modern developments.

Furthermore, the results of interviews conducted in several countries in Taniwel that there were several findings found from the interview that: The community needs state regulations that can protect customary values and all customary rights of indigenous peoples and their rules must be binding on all parties both legal subjects and objects customary law.

Thus, the attitudes taken by customary law communities through customary leaders in various places and opportunities call for them to hold firmly to maintain their culture with such appeals in principle showing to accept more modern kamajuan as long as they retain strong traditional values. On one hand customary values that are so strong can change if not properly maintained, then gradually it will be replaced with another era and soul.

\section{Closing}

\subsection{Conclusion}

From the explanation above, it can be concluded that:

1. The existence of customary communities' customary rights based on rules of ownership is still recognized, their traditional values are still preserved, still respected, respected, until now so that their existence is increasingly strengthened. And when times will change replaced with new regeneration.

2. Factors Affecting the Existence of Customary Rights in Modern Society can be influenced by cultural factors, structural factors, educational factors and legal factors.

3. Efforts in Maintaining the Existence of Customary Rights in Modern Communities, namely the principle of upholding traditional values.

\subsection{Suggestion}

1. It is expected that indigenous and tribal peoples will maintain the existence of customary rights of indigenous peoples in accordance with the nature and style of customary law in modern life

2. It is expected that there will be cooperation between the Government and the legal community in making domestic regulations that can bind legal subjects and and legal objects with the intent and purpose of protecting the rights of indigenous peoples,

\section{Books}

A.P.Parlindungan, Konversi Hak-hak atas tanah, Mandar Maju, Bandung, 1990

A. Suriyaman Mustari Pide, Hukum Adat Dahulu, Kini Dan Akan Datang, Prenada Media Group, Cet

${ }^{1}$ H. Abdurrahman Dan Tim Penyususn Draft Laporan Pengkajian Hukum Tentang Mekanisme Pengakuan Masyarakat Hukum Adat, Pusat Penelitian Dan Pengembangan Sistem Hukum Nasional Badan Pembinaan Hukum Nasional Kementerian Hukum Dan Hak Asasi Manusia R.I., Jakarta, 2015

${ }^{2}$ A. Latief Fariqun, Pengakuan Hak Masyarakat Hukum Adat Atas Sumberdaya Alam Dalam Politik Hukum Nasional, Disertasi Doktor Ilmu Hukum, Universitas Brawijaya, 2007, p. 81.

${ }^{3}$ Ibid. 
Pertama, Jakarta, 2014

Bambang Waluyo, Penelitian Hukum, PN, Sinar Grafika, Jakarta, 1991.

Bushar Muhammad, Pokok-Pokok Hukum Adat, PT Pradnya Paramita, Jakarta, 1981,

C.Van Vollenhoven Dalam Dominikus Rato, Hukum Adat (Suatu Pengantar Singkat Memahami Hukum Adat Di Indonesia), Laksbang Pressindo, Yogjakarta, 2011.

Djamanat Samosir, Hukum Adat Eksistensi Dalam Dinamika Perkembangan Hukum Di Indonesia, Cetakan I, Nuansa Aulia, Bandung, 2013.

Dominikus Rato, Hukum adat ( suatu pengantar singkat memahami hukum adat di Indonesia), Yogyakarta, Laksbang pressindo, 2011.

Djubedi, Hak Ulayat laut Di Era Otonomi Daerah, Genta, cet I, Yogjakarta

Frank L. Cooley, Mimbar dan Takhta, cetakan pertama, Pustaka Sinar Harapan, Anggota IKAPI, Jakarta, 1987.

H.Moh.Koesnoe, Kapita Selekta Hukum Adat Suatu Pemikiran Baru, Varia Peradilan, IKAHI, Jakarta, 2002

Husen Alting, Dinamika Hukum Dalam perlindungan Hak Masyarakat hukum Adat Atas Tanah, ( Masa lalu, Kini, dan Masa mendatang ), 2010

H. Muchisin, dkk, Hukum Agraria Indonesia Dalam Perspektif Sejarah, Refika Aditama , Bandung, 2010,

I Gede, A.B. Wiranata, Hukum Adat Indonesia, Perkembangannya Dari Masa Ke Masa, Citra Aditya Bakti, Cet 1, Bandung.

J. Supranto, Metode Penelitian dan Statistik, Rineka Cipta, Jakarta, 2003.

Jhonny Ibrahim, Teori dan Metodologi Penulisan Hukum Normatif, Banyumedia Publishing, Malang, 2012.

JB.Daliyo, Hukum Agraria I, Prenhallindo, Jakarta, 2001

Kurnia Warman, Hukum Agraria Dalam Masyarakat Majemuk, HuMa, Jakarta, 2010

Maria,S.W. Sumardjono, Kebijakan Pertanahan; Antara Regulasi Dan Implemantasi, Kompas, Cet III, Jakarta, 2005.

Philipus M. Hadjon, Perlindungan Hukum Bagi Rakyat Indonesia, Bina Ilmu, Surabaya, 1987.

Rikardo Simarmata, Pengakuan Hukum terhadap Masyarakat Adat di Indonesia, UNDP, Jakarta, 2006

R.Soeprapto, Undang-Undang Agraria Dalam Praktek, Mitra Sari, Jakarta, 1966.

Suriyaman Mustari Pide, Hukum Adat Dahulu, Kini Dan Akan Datang, PrenadaMedia Group, Cet Pertama, Jakarta, 2014.

Satijipto Raharjo, Ilmu Hukum, Citra Aditya Bakti, Bandung, 2000.

Sarkawi, Hukum Pembebasan Tanah Hak Milik Adat Untuk Pembangunan Kepentingan Umum, Graha Ilmu, Yogyakarta, 2014

Soerjono Soekanto, Pengantar Penelitian Hukum, Universitas Indonesia, Jakarta, 1984.

Ziwar effendi, Hukum Adat Ambon-Lease, Pradnya Paramita, Jakarta, 1987

Etc

A. Latief Fariqun, Pengakuan Hak Masyarakat Hukum Adat Atas Sumberdaya Alam Dalam Politik Hukum Nasional, Disertasi Doktor Ilmu Hukum, Universitas Brawijaya, 2007

Achmad Sodiki, Penataan Kepemilikan Hak Atas Tanah Di Daerah Perkebunan Kabupaten Malang (Studi Tentang Dinamika Hukum), Disertasi Program Pasca Sarjana Universitas Airlangga, Surabay, 1994

H. Abdurrahman, Peranan Hukum Adat Dalam Aplikasi Kehidupan Berbangsa Dan Bernegara Dalam Majalah Hukum Nasional, No. 1 Tahun 2007 , BPHN Departemen Hukum Dan HAM RI

Dan Tim Penyususn Draft Laporan Pengkajian Hukum Tentang Mekanisme Pengakuan Masyarakat Hukum Adat, Pusat Penelitian Dan Pengembangan Sistem Hukum Nasional Badan Pembinaan Hukum Nasional Kementerian Hukum Dan Hak Asasi Manusia R.I., Jakarta, 2015

Naskah Akademis RUU Pengakuan dan Perlindungan Hak Masyarakat Hukum Adat.

http://artikelcore.blogspot.co.id/2014/08/Masyarakat-Tradisional-Dan-Masyarakat-Modern.html. 